\title{
PERANAN SUPERVISI AKADEMIK KEPALA SEKOLAH BAGI PENINGKATAN KOMPETENSI GURUSEKOLAH DASAR
}

\author{
Sri Endang Mulyati ${ }^{1}$ \\ SDN Kubangwungu 01 Brebes Jawa Tengah \\ sriendangmulyati@yahoo.co.id
}

\begin{abstract}
Principal is a teacher who was given the obligation to manage existing resources in a school. One of the principal efforts in the school success is his/her role and guidance to the teachers. If the coaching process to the teacher is done properly the professionalism of teachers can be improved. The professionalism of teachers in implementing the learning activities in the classroom are very important for the progress of the school. Teacher's professionalism and competency in learning-studying activities will correlated with student achievement in shortterm, and it will also improve the quality and reputation of the school in longterm.This article is a report of a qualitative approach - field research study entitled "The Improvement of Teacher Competency Through Academic Supervision of SDN Kubangwungu 01" The subjects in this study were SDN Kubangwungu 01 teachers, in first semester of academic year 2015-2016"This study used data collection methods while the analysis of the data used is descriptive-qualitative analysis.The results of this study indicate that the Principal was instrumental in improving the quality of learning in schools.Principal improved the competency and professionalism of teachers using supervision method. Professionalism and performance of teachers in implementing learningactivities in the classroomis increased by Principal leadership through regular coaching and supervision.
\end{abstract}

Keywords: Leadership, Principals, Teacher, Professionalism, Competency

${ }^{1}$ Guru SD Kubangwungu 01 Kabupaten Brebes, Peneliti 


\section{Pendahuluan}

Dalam sistem pendidikan di Indonesia, matematika merupakan satusatunya bidang studi yang dipelajari secara eksplisit mulai dari tingkat taman kanakkanak hingga perguruan tinggi. Mata pelajaran matematika perlu diberikan kepada semua peserta didik mulai dari sekolah dasar untuk membekali peserta didik dengan kemampuan berpikir logis, analitis, sistematis, kritis, dan kreatif, serta kemampuan bekerja sama. Kompetensi tersebut diperlukan agar peserta didik dapat memiliki kemampuan memperoleh, mengelola, dan memanfaatkan informasi untuk bertahan hidup pada keadaan yang selalu berubah, tidak pasti, dan kompetitif. Melalui pembelajaran matematika inilah diharapkan bangsa dapat meningkatkan kualitas sumber daya manusianyasehingga individu-individu generasi penerus bangsa dapat bangkit untuk memajukan bangsa dan negaranya.

Menurut Sugiarto (2009: 11) matematika merupakan ilmu universal yang mendasari perkembangan teknologi modern, mempunyai peran penting dalam berbagai disiplin dan memajukan daya pikir manusia.Dalam Permendiknas No. 22 Tahun 2006 menjelaskan bahwa tujuan mata pelajaran matematika adalah agar siswa memiliki kemampuan sebagai berikut:

(1) Memahami konsep matematika, menjelaskan keterkaitan antarkonsep dan mengaplikasikan konsep atau algoritma, secara luwes, akurat, efisien, dan tepat, dalam pemecahan masalah. (2) Menggunakan penalaran pada pola dan sifat, melakukan manipulasi matematika dalam membuat generalisasi, menyusun bukti, atau menjelaskan gagasan dan pernyataan matematika.

Memecahkan masalah yang meliputi kemampuan memahami masalah, merancang model matematika, menyelesaikan model dan menafsirkan solusi yang diperoleh.

Mengomunikasikan gagasan dengan simbol, tabel, diagram, atau media lain untuk memperjelas keadaan atau masalah. (5) Memiliki sikap menghargai kegunaan matematika dalam kehidupan, yaitu memiliki rasa ingin tahu, perhatian, dan minat dalam mempelajari matematika, serta sikap ulet dan percaya diri dalam pemecahan masalah.

Berdasarkan tujuan pembelajaran matematika di atas nampak jelas bahwa kemampuan memecahkan masalah merupakan salah satu tujuan yang diharapkan diperoleh siswa setelah memperoleh pembelajaran matematika.Menurut Montague (dalam Ruzi dan Muzakir, 2015) pada dasarnya pemecahan masalahmempunyai dua langkah, yaitu representasimasalah dan menyelesaikan masalah.Pemecahan masalah yang sukses tidakmungkin tanpa representasi masalah yangsesuai. Representasi masalah yang sesuaiadalah dasar untuk memahami masalah danmembuat suatu rencana untuk memecahkanmasalah. Siswa yang mempunyai kesulitan dalam merepresentasikan masalah matematika akan memiliki kesulitan dalam melakukan pemecahan masalah.Dengan demikian seiring dengan pentingnya kemampuan pemecahan masalah dalam pembelajaran matematika, maka kemampuan representasi matematis sebagai bagian yang tak terpisahkan dari pemecahan masalah juga berperan dalam pembelajaran matematika. Dalam memecahkan masalah, siswa dituntut untuk mampu membuat model matematika dari masalah yang diberikan, menyelesaikan model tersebut dan menafsirkan penyelesaian yang diperoleh. Kemampuan dalam menyajikan kembali berbagai ide untuk memperjelas masalah dan kemampuan merancang model penyelesaian serta menafsirkan penyelesaian dari masalah itulah yang tercakup dalam kemampuan representasi matematis. 
Representasi merupakan salah satu dari lima standar proses yang tercantum dalam NCTM (Principle and Standard for Mathematics Education) bersama dengan empat kompetensi lainnya yang harus dimiliki oleh setiap siswa yaitu pemecahan masalah, penalaran dan pembuktian, komunikasi, serta koneksi yang semuanya merupakan bagian dari proses berpikir matematis. Dalam program pembelajaran matematika NCTM menekankan agar siswa dilatih kemampuan representasi matematisnya. Hal ini untuk membantu perkembangan pemahaman matematis sehingga siswa mampu:

1. Membuat dan menggunakan representasi untuk mengatur, mencatat, dan mengomunikasikan ide-ide.

2. Mengembangkan suatu bentuk perwujudan dari representasi matematis yang dapat digunakan dengan tujuan tertentu, secara fleksibel dan tepat

3. Mengomunikasikan representasi untuk memodelkan dan menginterpretasikan fenomena fisik, sosial, dan matematis.

Dalam standar kurikulum NCTM dijelaskan bahwa representasi adalah proses memodelkan dan menginterpretasikan fenomena fisik, sosial, dan matematika dengan penuh arti untuk meningkatkan pemahaman (Hatfield, 2008: 7). Menurut NCTM, representasi yang dibuat oleh siswa merupakan bentuk ungkapan dari ide-ide yang mereka peroleh untuk menemukan solusi dari permasalahan yang dihadapinya. Ada tiga standar kemampuan representasi matematika yang ditetapkan oleh NCTMuntuk pogram pembelajaran dari prataman kanak-kanak hingga kelas 12 standar pertama adalah siswa mampu membuat dan menggunakan representasi untuk mengorganisasikan, mencatat dan mengkomunikasikan semua ide-ide matematika. Kemudian standar kedua, siswa mampu memilih, menerapkan, dan menerjemahkan antar representasi matematis untuk memecahkan masalah. Standar ketiga adalah siswa mampu menggunakan representasi untuk memodelkan dan menginterpretasikan fenomena fisik, sosial, dan matematika.

Representasi digunakan secara luas dalam bidang kajian matematika karena representasi dapat membantu siswa untuk mengembangkan, berbagi, dan menyajikan situasi masalah nyata kedalam bahasa matematis.Untuk itu guru perlu mengembangkan dan melatih siswa meningkatkan kemampuan representasinya dalam menyelesaikan suatu masalah yang diberikan. Karena apabila kemampuan representasi siswa itu baik, maka diharapkan siswa juga memiliki kemampuan pemecahan masalah, penalaran, komunikasi matematis dan koneksi matematis yang baik pula. yang tentunya akan menghasilkan pembelajaran yang lebih bermakna.

Dari paparan di atas dapat disimpulkan bahwa kemampuan representasi matematis merupakan hal yang sangat penting dimiliki oleh siswa sekolah dasar. Pentingnya kemampuan representasi matematis dalam pembelajaran matematika diungkapkan oleh Kartini (2009: 361). Ia menyatakan bahwa representasi berperan dalam membantu memahami konsep, mengkomunikasikan dan memecahkan permasalahan. Sejalan dengan pendapat tersebut, Hwang, et al.(2007: 209), dalam penelitiannya menyimpulkan bahwa kemampuan representasi merupakan kunci bagi siswa untuk dapat memecahkan permasalahan dengan baik. Lebih lanjut ia menjelaskan, kemampuan representasi, khususnya pada aspek text or voice representation dan aspek graph or symbol representation, memegang peranan yang paling penting dalam mengubungkan proses pembelajaran antara proses mengingat (remembering), memahami (understanding), dan mengaplikasikan (applying). Dari pendapat tersebut, untuk dapat memecahkan masalah siswa harus memiliki kemampuan representasi yang baik, sehingga dapat dikatakan bahwa 
kemampuan representasi merupakan alat untuk mencapai kemampuan pemecahan masalah yang baik.

Uraian di atas menunjukkan bahwa kemampuan representasi memiliki peranan penting dalam pembelajaran matematika. Namun dalam kenyataannya, pembelajaran konvensional yang masih diterapkan oleh beberapa sekolah di Indonesia belum dapat mengembangkan

kemampuan representasinya.Seperti apa yang diungkapkan oleh Hudiono (2005: 191) dalam penelitiannya, ia menyimpulkan bahwa pembelajaran konvensional belum cukup efektif untuk mengembangkan kemampuan representasi secara optimal.

$\begin{array}{ccr}\text { Lebih lanjut peneliti melakukan } \\ \text { observasi } & \text { prapenelitian } & \begin{array}{r}\text { dengan } \\ \text { mang }\end{array}\end{array}$ memberikan tes untuk mengetahui tingkat kemampuan representasi matematis siswa di sekolah tempat peneliti melakukan penelitian, yaitu SDN Cijati. Berdasarkan hasil observasi di salah satu kelas pada tingkatan kelas $\mathrm{V}$, persentase skor kemampuan representasi matematis siswa pada indikator representasi visual mencapai $31,26 \%$, representasi berupa ekspresi matematis $29,11 \%$, dan representasi berupa teks tertulis $42,51 \%$. Keseluruhan persentase skor kemampuan representasi matematis siswa hanya mencapai $34,29 \%$. Secara umum terlihat bahwa kemampuan representasi matematis siswa memang masih rendah.

Selain itu sebuah survey Trends International Mathematics and Science Study(TIMSS) yang diselenggarakan oleh International Association for the Evaluation of Education Achievement (IEA), sebuah lembaga studi international yang meneliti kecenderungan atau perkembangan matematika dan sains,mengungkapkan bahwa pada TIMSS tahun 2011, posisi Indonesia menempati peringkat ke-40 dari 42 negara dengan nilai rata-rata 406.

Dari studi tersebut juga terungkap bahwa siswa Indonesia masih lemah dalam menyelesaikan soal-soal tidak rutin yang berkaitan dengan pembuktian, pemecahan masalah yang memerlukan penalaran matematika, menemukan generalisasi atau konjektur, dan menemukan hubungan antara data-data atau fakta yang diberikan. Berdasarkan fakta di atas, dapat dikatakan bahwa kemampuan pemecahan masalah, kemampuan berpikir kritis, kreatif, dan repesentasi matematis siswa pada umumnya masih rendah.

Mengingat begitu pentingnya kemampuan representasi matematis dimiliki oleh siswa dan masih sedikitnya sekolah-sekolah di Indonesia yang menerapkan sebuah pembelajaran yang dapat mewadahi perkembangan kemampuantersebut, maka diperlukan suatu alternatif pembelajaran yang memberikankesempatan kepada siswa untuk dapat mengembangkan kemampuan representasimatematisnya tersebut.

Peneliti selanjutnya mencoba menerapkan model pembelajaran CollaborativeProblem Solvingyang diduga dapat memberikan kesempatan kepada siswa mengambangkan kemampuan representasinya. Pada model pembelajaran ini,siswa dihadapkan padapermasalahan yang harus diselesaikan secara individu dan kelompok.Permasalahan yang diberikan akan menstimulus siswa untuk merepresentasikanide-idenya terkait masalah itu sedemikian sehingga mereka dapat menemukanpenyelesaiannya.

Collaborative dapat diartikan sebagai kolaborasi atau kerja sama. Marjan dan Mozhgan (2012: 491) mengartikan collaborative learning sebagai suatu pendekatan pengajaran dan pembelajaran yang melibatkan sekelompok siswa untuk bekerja bersama dalam memecahkan masalah, melengkapi tugas, dan menciptakan suatu produk. Sementara Smith dan MacGregor (dalam Marjan dan Mozhgan, 2012: 492) mendefinisikan collaborative learning sebagai suatu istilah yang memasukkan berbagai pendekatan 
pendidikan yang melibatkan hubungan intelektual antarsiswa, atau antara siswa dengan guru secara bersama-sama. Pada umumnya siswa bekerja dalam kelompok yang beranggotakan dua orang atau lebih, satu sama lain saling mencari pemahaman, solusi, pengertian, atau menciptakan suatu produk. Sedangkan menurut Dillenbourg (1999: 7), Collaborative ProblemSolving adalah suatu kerja sama yang dilakukan oleh dua orang atau lebih yangmemiliki tujuan yang sama yaitu untuk menyelesaikan suatu permasalahantertentu. Pembelajaran ini menjadikan proses kerja sama antarsiswa dalammenyelesaikan permasalahan sebagai hal utama untuk dapat mengkonstrukpengetahuannya sendiri, berbekal pengetahuan awal yang dimiliki oleh masing-masingsiswa.

Menurut Gunawan (2007: 198) terdapat lima unsur penting dalam proses pembelajaran kolaboratif, yaitu:

1) Adanya rasa kebersamaan;

2) Adanya interaksi yang saling mendukung antar anggota kelompok satu sama lain;

3) Adanya rasa tanggung jawab secara individu dan kelompok untuk keberhasilan proses pembelajaran;

4) Kemampuan komunikasi yang baik antarpribadi dalam suatu kelompok kecil;

5) Adanya proses refleksi terhadap fungsi dan kemampuan mereka bekerja sama sebagai suatu kelompok.

\section{Adapun Collaborative Problem}

Solving menurut Nelson (1999: 245) merupakan kombinasi antara dua pendekatan pembelajaran, yaitu pembelajaran kerja sama dan pembelajaran berbasis masalah. Kedua pembelajaran ini sebenarnya memungkinkan untuk menciptakan lingkungan belajar kolaboratif, namun tidak komprehensif. Lingkungan belajar yang mendukung siswa untuk berkolaborasi secara natural dan efektif sangat penting untuk didesain agar mereka dapat mengembangkan pengetahuan melalui pengalamannya sendiri. Untuk memenuhi kebutuhan tersebut, maka dibuatlah desain pembelajaran Collaborative Problem Solving yang didukung oleh kegiatan pemecahan masalah siswa dimana siswa dapat melakukan kesepakatan, didasarkan pada proses kolaboratif alami mereka masing-masing.

Menurut Widjajanti (2008: 7), langkah pembelajaran kolaboratif berbasis masalah adalah sebagai berikut:

1) Pembelajaran diawali dengan pemberian masalah yang menantang;

2) Siswa diberi kesempatan untuk mengidentifikasi dan merancang penyelesaian permasalahan tersebut secara individu sebelum mereka belajar dalamkelompok;

3) Siswa belajar dalam kelompok kecil yang beranggotakan 4-6 orang untukmengklarifikasi pemahaman mereka, mengkritisi ide teman dalamkelompoknya, membuat konjektur, memilih strategi penyelesaian, dan menyelesaikan masalah yang diberikan, dengan cara saling beradu argumen.

4) Setelah itu siswa menyelesaikan masalah yang diberikan guru secaraindividual;

5) Siswa mempresentasikan hasil penyelesaian masalah yang diperoleh.

\section{Metode Penelitian}

Penelitian ini merupakan penelitian kuasi eksperimen dengan desain pretest posttest control groupdesign. Dalam penelitian kuasi eksperimen subyek penelitian tidak dikelompokkan secara acak akan tetapi subyek diterima apa adanya. Hal ini karena kelas sudah terbentuk sebelumnya. Desain eksperimen dalam penelitian ini disajikan pada rancangan berikut :

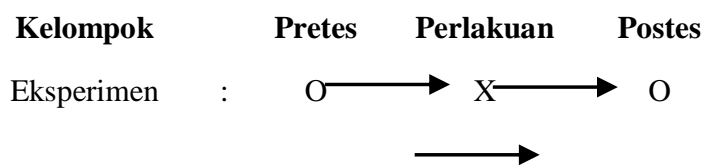


Kontrol

Syaodih (2013: 207)

Populasi dalam penelitian ini adalah seluruh siswa kelas SD kelas V TahunPelajaran 2015/2016 sekecamatan Panyingkiran. Teknik pengambilan sampel menggunakan purposive sampling.Sampel dalam penelitian ini terdiri dari dua kelompok, yaitu kelompok eksperimen dankelompok kontrol. Pada kelompok eksperimen diberikan pembelajaran Collaborative Problem Solving, sedangkan pada kelompok kontrol diberikan pembelajaran konvensional. Instrumendalam penelitian ini adalah soal tes kemampuan representasi matematis.

\section{Hasil Penelitian}

Pada kedua kelompok diberikan pretest untuk mengetahui kemampuan awal siswa sebelum diberi perlakuan. Kemampuan awal siswa tercermin dari hasil pretest kemampuan representasi matematis. Rata-rata skor pretest kemampuan representasi matematis siswa pada kelompok eksperimen adalah 8,086 sedangkan pada kelompok kontrol diperoleh rata-rata 8,063.

Setelah diberikan perlakuan, ratarata skor posttest kemampuan representasi matematis siswa yang memperoleh pembelajaran Collaborative Problem Solving adalah 13,343 dan untuk siswa yang memperoleh pembelajaran konvensional adalah 12,630. Rata-rata skor posttest kemampuan representasi matematis siswa yang memperoleh pembelajaran Collaborative Problem Solving lebih tinggi daripada rata-rata skor posttest kemampuan representasi matematis siswa yang memperoleh pembelajaran konvensional.

\section{Uji Normalitas}

Dalam melakukanuji normalitas, penulis menggunakan bantuanSPSS 20 dengan Uji Kolmogorov-Smirnov pada taraf signifikansi $\alpha=0,05$.Adapun perumusan hipotesis untuk uji normalitas adalah sebagai berikut:

$\mathrm{H}_{0}$ : Data berdistribusi normal.

$\mathrm{H}_{1}$ : Data tidak berdistribusi normal.

Kriteria pengujian hipotesis berdasarkan P-value (significance atau sig) sebagai berikut:

Jika sig $<\propto$ dengan $\propto=0,05$, maka $\mathrm{H}_{0}$ ditolak

Jikasig $\geq \propto$ dengan $\propto=0,05$, maka $\mathrm{H}_{0}$ diterima

Hasil uji normalitas skor kemampuan representasi matematis siswasebelum diberi perlakuan sebagai berikut :

Tabel 1

Hasil Uji Normalitas Skor Pretes

\begin{tabular}{|c|c|c|c|c|}
\hline \multirow{2}{*}{ Kel. } & \multicolumn{2}{|c|}{ Kolmogorov- } & \multirow{2}{*}{ Kesimpulan } & \multirow{2}{*}{ Ket. } \\
\cline { 2 - 3 } & Stat. & Sig. & & \\
\hline Eksp & 0,125 & 0,184 & $\mathrm{H}_{0}$ diterima & Normal \\
\hline Kon. & 0,150 & 0,065 & $\mathrm{H}_{0}$ diterima & Normal \\
\hline
\end{tabular}

Pada Tabel di atas nampak bahwa pada kolom Kolmogorov-Smirnov nilai sig.kemampuanrepresentasi siswa pada kedua kelompok lebih besar daria $=0,05$ dengan demikian $\mathrm{H}_{0}$ diterima, sehingga penyebaran data skor kemampuanrepresentasi matematis siswa sebelum diberi perlakuan berdistribusi normal.

Adapun hasil uji normalitas skor kemampuan representasi matematis siswa setelah diberi perlakuan adalah sebagai berikut :

Tabel 2

Hasil Uji Normalitas Skor Postes

\begin{tabular}{|c|c|c|c|c|}
\hline \multirow{2}{*}{ Kel. } & \multicolumn{2}{|c|}{$\begin{array}{c}\text { Kolmogorov- } \\
\text { Smirnov }\end{array}$} & \multirow{2}{*}{ Kesimpulan } & \multirow{2}{*}{ Ket. } \\
\cline { 2 - 3 } & Stat. & Sig. & & \\
\hline Eksp & 0,137 & 0,093 & $\mathrm{H}_{0}$ diterima & Normal \\
\hline Kon. & 0,152 & 0,059 & $\mathrm{H}_{0}$ diterima & Normal \\
\hline
\end{tabular}


Pada Tabel di atas nampak bahwa pada kolom Kolmogorov-Smirnov nilai sig. untuk kemampuanrepresentasi matematis siswa yang memperoleh pembelajaran Collaborative Problem Solving dan siswa yangmemperoleh pembelajaran konvensional lebih besar dari $\alpha=0,05$ dengan demikian Hoditerima, sehingga penyebaran data skor posttest kemampuan representasi matematis siswayang memperoleh pembelajaran Collaborative Problem Solving maupun konvensional berdistribusi normal.

\section{Uji Homogenitas}

Uji homogenitas bertujuan untuk mengetahui kedua kelas sampel mempunyai varians yang homogen atau tidak. Pengujian homogenitas varians dilakukan dengan uji statistik Levene's test dengan taraf signifikansi 5\%. Berikut ini rumusan hipotesisnya:

$$
\begin{array}{rlr}
\mathrm{H}_{0}: \sigma_{1}^{2}=\sigma_{2}^{2}, & \text { varians data } \\
& \text { kemampuan matematis } \\
& \text { siswa kedua kelas } \\
& \text { homogen. } \\
\mathrm{H}_{1}: \sigma_{1}^{2} \neq \sigma_{2}^{2}, & \text { varians data } \\
& \text { kemampuan matematis } \\
& \text { siswa kedua kelas } \\
& \text { tidak homogen. }
\end{array}
$$

Kriteria pengujian hipotesis berdasarkan P-value (significance atau sig) sebagai berikut:

Jika $\operatorname{sig}<\propto$ dengan $\propto=0,05$, maka $\mathrm{H}_{0}$ ditolak

Jikasig $\geq \propto$ dengan $\quad \propto=0,05$, maka $\mathrm{H}_{0}$ diterima

Hasil uji homogenitas terhadap data skor kemampuan representasi matematis siswa sebelum diberi perlakuan disajikan pada tabel berikut :

Tabel 3

Hasil Uji Homogenitas Skor Postes

\begin{tabular}{|c|c|c|}
\hline $\begin{array}{c}\text { Homogenity of } \\
\text { Variance }\end{array}$ & Kesimpulan & Keterangan \\
\hline
\end{tabular}

\begin{tabular}{|c|c|c|c|}
\hline $\begin{array}{c}\text { Levene } \\
\text { Statistic }\end{array}$ & Sig. & & \\
\hline 0,096 & 0,758 & $\mathrm{H}_{0}$ diterima & Homogen \\
\hline
\end{tabular}

Berdasarkan data yang disajikan tabel di atas nampak bahwa pada kolom Homogeneity of Variance, nilai sig. kemampuanrepresentasi matematis lebih besar dari $\alpha=0,05$ maka $\mathrm{H}_{0}$ diterima,yang berarti bahwa variansi skor pretest kemampuan representasi matematis kelompok eksperimen dan kelompok kontrol homogen.

Adapun hasil uji homogenitas terhadap data skor kemampuan representasi matematis siswasetelah diberi perlakuan disajikan pada tabel berikut :

Tabel 4

Hasil Uji Homogenitas Skor Postes

\begin{tabular}{|c|c|c|c|}
\hline \multicolumn{2}{|c|}{$\begin{array}{c}\text { Homogenity of } \\
\text { Variance }\end{array}$} & \multirow{2}{*}{ Kesimpulan } & Ket. \\
\cline { 1 - 2 } $\begin{array}{c}\text { Levene } \\
\text { Statistic }\end{array}$ & Sig. & & \\
\hline 0,216 & 0,644 & $\mathrm{H}_{0}$ diterima & Homogen \\
\hline
\end{tabular}

Pada Tabel di atas nampak bahwa pada kolom Homogeneity of Variance, nilai sig. lebih besar dari $\alpha=0,05$ maka $\mathrm{H}_{0}$ diterima, yang berarti bahwa variansi skor posttest kemampuanrepresentasi matematis siswa pada kelas eksperimen dan kelas kontrol homogen.

\section{Uji Perbedaan Rata-rata}

Data skor kemampuan representasi matematis siswa sebelum diberiperlakuan berdistribusi normal dan homogen, maka untuk mengetahui sama atau tidaknyaratarata kemampuan representasi matematis siswa sebelumdiberikan perlakuan dilakukan uji kesamaan rata-rata dengan uji t. Pengujian hipotesismenggunakan software SPSS 20 dengan uji t (compare means independent samples $t$ test)pada taraf signifikansi $\alpha=0,05$ dengan kaidah pengambilan keputusan bila nilai $p$-value $($ sig $)<\alpha$ maka tolak $\mathrm{H}_{0}$.

$\mathrm{H}_{0}: \mu_{\mathrm{e}}=\mu_{\mathrm{k}}$

$\mathrm{H}_{1}: \mu_{\mathrm{e}}>\mu_{\mathrm{k}}$ 
Hasil uji t terhadap skor kemampuan representasi matematis siswasebelum diberi perlakuan disajikan pada tabel berikut ini :

Tabel 5

Hasil Uji Perbedaan

Rata-rata Skor Pretes

\begin{tabular}{|c|c|c|c|}
\hline $\mathrm{t}$ & Sig. & Kesimpulan & Ket. \\
\hline 0,033 & 0,974 & $\mathrm{H}_{0}$ diterima & $\begin{array}{c}\text { Tidak terdapat } \\
\text { perbedaan }\end{array}$ \\
\hline
\end{tabular}

Dari hasil uji t diperoleh nilai sig. kemampuan representasi matematis lebih besar dari $\alpha=0,05$ sehingga $\mathrm{H}_{0}$ diterima. Hal ini berarti sebelum dilakukaneksperimen kedua kelompok memiliki kemampuan awal yang sama pada aspek kemampuanrepresentasi.

Berdasarkan hasil uji normalitas dan uji homogenitas terhadap skor kemampuan representasimatematis siswa setelah diberi perlakuan ditemukan bahwa data skor posttest kemampuan representasi matematis pada kedua kelas berdistribusi normal dan homogen. Oleh karena itu, untuk mengetahui sama atau tidaknya kemampuan representasi matematis, maka dilakukan uji kesamaan rata-rata dengan uji t. Hasil uji t terhadap skor posttest kemampuan representasi matematis disajikan pada tabel berikut ini :

Tabel 6

Hasil Uji Perbedaan

Rata-rata Skor posttest

\begin{tabular}{|c|c|c|c|}
\hline $\mathrm{t}$ & Sig. & Kesimpulan & Keterangan \\
\hline 2,130 & 0,037 & $\mathrm{H}_{0}$ ditolak & $\begin{array}{c}\text { Terdapat } \\
\text { perbedaan }\end{array}$ \\
\hline
\end{tabular}

Berdasarkan data yang disajikan pada tabel di atas terlihat bahwa nilai sig. lebih kecil dari $\alpha=0,05$ maka Ho ditolak. Hal ini berarti kemampuan representasi matematis siswa yang diberikan perlakuan dengan pembelajaran Collaborative Problem Solving lebih baik daripada kemampuan representasi matematis siswa yang diberi perlakuan dengan pembelajaran konvensional.

\section{Pembahasan}

Penelitian ini bertujuan untuk melihat peningkatan kemampuan representasi matematis siswa setelah diberikan model pembelajaran Collaborative Problem Solving.Sebelum diberikan perlakuan, kedua kelompok diberikan pretest untuk mengetahui kemampuan awal siswa pada aspek kemampuan representasi matematis. Setelah perlakuan, kedua kelompok diberikan posttest untuk mengetahui peningkatan kemampuan representasi matematis. Hasil uji normalitas dan uji homogenitas terhadap data skor kemampuan representasi matematis siswa sebelum diberi perlakuan diperoleh hasil bahwa populasi berdistribusi normal dan homogen. Selanjutmya, dari hasil uji t pada taraf signifikansi $\alpha=0,05$ terhadap skor kemampuan representasi matematis siswa sebelum diberi perlakuan diperoleh hasil bahwa tidak terdapat perbedaan kemampuan awal representasi matematis siswa, atau dengan kata lain, sebelum diberi perlakuan, kedua kelompok memiliki kemampuan representasi matematis yang setara.

Setelah diberikan perlakuan, ratarata skor kemampuan representasi matematis siswa yang memperoleh pembelajaran Collaborative Problem Solving lebih tinggi daripada rata-rata skor kemampuan representasi matematis siswa yang memperoleh pembelajaran konvensional. Skor kemampuan representasi matematis siswa yang diberi perlakuan dengan pembelajaran Collaborative Problem Solvingdiperoleh rata-rata 12,743 sedangkan rata-rata skor kemampuanrepresentasi matematis siswa yang diberi perlakuan pembelajaran konvensionaladalah 11,719.

Setelah siswa diberikan perlakuan, terjadi peningkatan kemampuan representasi matematis baik pada 
kelompok eksperimen dan kelompok kontrol. Peningkatan kemampuan representasi matematis siswa yang memperoleh pembelajaran Collaborative Problem Solving lebih tinggi daripada siswa yang memperoleh pembelajaran konvensional. Hal ini menunjukkan bahwa model pembelajaran Collaborative Problem Solving ternyata dapat meningkatkan kemampuan representasi matematis siswa.

\section{Kesimpulan dan Saran}

Hasil penelitian ini menunjukkan bahwa kemampuan representasi matematis siswa yang memperoleh pembelajaran Collaborative Problem Solvinglebih baik daripadasiswa yang memperoleh pembelajaran konvensional. Sebagai kesimpulan, penelitian inimembuktikan bahwa model pembelajaran Collaborative Problem Solvingdapat meningkatkankemampuan representasi matematis siswa.

Saran yang dapatdikemukakan adalah perlu adanya penelitian lanjutan untuk mengkaji pembelajaran Collaborative Problem Solvingdalam meningkatkan kemampuanmatematis yang lainnya.

\section{Daftar Pustaka}

Dillenbourg, "What Do You Mean by 'Collaborative Learning'?", dalam P.Dillenbourg (ed), Collaborativelearning: Cognitive and Computational Approaches, (Oxford:Elsevier, 1999), p. 7

Gunawan, A. W.(2007), Genius Learning Strategy, Jakarta: PT Gramedia Pustaka Utama, Cet. Ke-IV.

Hatfield, et al., (2008).Mathematics Method For Elementary and Middle School Teachers SixthEdition, (Hoboken: John Wiley and Sons Inc.), p. 7
Hudiono,B. (2005) "Peran Pembelajaran Diskursus Multi Representasi Terhadap Pengembangan Kemampuan Matematik dan Daya Representasi pada Siswa SLTP", Disertasi padaSekolah Pascasarjana UPI, Bandung:

Kartini, (2009) "Peranan Representasi Dalam Pembelajaran Matematika", Prosiding SeminarNasional Matematika dan Pendidikan Matematika Jurusan Pendidikan Matematika (Yogyakarta:FMIPA UNY), h. 361-362

Marjan, L. and Mozhgan, L., (2012)"Collaborative learning: what is it?", Proccedia-Sosialand Behavioral Sciences 31, (Oxford: Elsevier),

Nelson, ML, (1999). "Collaborative Problem Solving", dalam Reigeluth (ed), Instructional-Design Theories and Models A New Paradigm of Instructional Theory, (New York:Lawrence Erlbaum Associates, Inc.)

Ruzi, F. Dan Muzakir, Ully. (2015). Numeracy : Jurnal Ilmiah Pendidikan Matematika. Pengaruh Pendekatan Pembelajaran Problem Posing Terhadap Kemampuan Representasi Matematika Siswa Pada Materi Bangun Datar Segi Empat. Vol 2 no 1. Hal 1-12

Syaodih, N. (2013). Metode Penelitian Pendidikan. Bandung. PT Remaja Rosdakarya.

Sugiarto. 2009. Bahan Ajar Workshop Pendidikan Matematika I. Semarang: Jurusan Matematika UNNES

Widjajanti, (2008). "Strategi Pembelajaran Kolaboratif Berbasis 

Masalah",Prosiding Seminar
Nasional Matematika dan
Pendidikan Matematika,
(Yogyakarta: FMIPA UNY)

Wu-Yuin Hwang, et. al., (2007). "Multiple

Representation Skills and

Creativity Effects onMathematical

Problem Solving using a

Multimedia Whiteboard System",

Educational Technology\& Society, Vol. 10 No. 2, International Forum of Educational Technology \& Society (IFETS),p. 209 